\title{
The armchair balloonist
}

\section{Gordon L. Herries Davies}

Theories of the Earth and Universe: A History of Dogma in the Earth Sciences. By S. Warren Carey. Stanford University Press: 1988. Pp.413. \$45.

Polygenous is the first adjective to apply to this book. Professor Carey - a doyen among Australian geologists - has given us a work that is part autobiography, part history of science, part treatise upon global tectonics and part speculative cosmclogy. It is indeed a rare amalgam which Carey himself describes as "this armchair philosophy of an aging scientist". But despite its divers themes, the book does have an overall cohesion. Earth scientists will find it a thought-provoking work even though it will raise many a hackle.

Carey is convinced that the modern theory of plate tectonics is a false dogma. $\mathrm{He}$ accepts the theory in so far as it invokes seafloor spreading, but he rejects the notion that a balance is maintained between the creation of new crust along the mid-ocean ridges and the destruction of old crust along zones of subduction. For Carey, subduction is a myth. In his eyes the Earth's surface is not the site of a steady-state economy. There is no need, he claims, for the accruing income at the mid-ocean ridges to be balanced by the expenditure of subduction, because the Earth, like a great balloon, is steadily expanding at an exponential rate. For most geologists, Carey's views are neither welcome nor acceptable. That eminent professor who at the close of one of Carey's expositions rose and exclaimed "Bull-shit!" may have wanted manners but he expressed the consensus of the scientific community. Carey nevertheless remains unabashed.

The book opens with obeisance to Clio. Carey seeks to show that his own position is by no means unique. He claims that throughout the history of the Earth sciences prevailing dogma has repeatedly hindered the acceptance of important new ideas. He offers as exemplars of his thesis such familiar cases as the debate over the nature of fossils, the controversy between the neptunists and the plutonists, and the battle that raged around the glacial brainchild of Louis Agassiz. This is the least satisfactory part of the book. My complaints are twofold. First, there are a large number of small factual errors, and secondly - and far more importantly - I found Carey's whiggish interpretation of history to be quite unacceptable. He presents the history of his science in terms of 'baddies' and 'goodies'. He sees his baddies as the blinkered obstructionists who clung to outmoded dogma and who thus hindered the forward march of science. His goodies were those who, in his eyes, struggled valiantly to establish what we now hold to be scientific truth.

This simplistic interpretation will not do. Carey's baddies were never the myopic dunderheads that he implies. Rather they were scientists just as able as any of our own day and equally resolute both in their search for truth and in their combating of what they saw as error. Carey throws one of his darts at William Richardson, that wernerian geologist who, early in the last century, refused to see the significance of a site shown to him by some huttonians upon Edinburgh's Salisbury Crags. But please reflect. Richardson was an Irish geologist deeply experienced in the basaltic landscapes of his native land. Why should this demonstration of a small piece of sandstone set within trap be expected to shake a man's long-cherished and carefully reasoned belief in the wernerian theory? Would Carey allow just one geological section to subvert his own 30-year-old belief in an expanding Earth? The relationship between what the geologist sees and what the geologist believes is far more complex than Carey's historical review would suggest.

In the second part of the book, Carey outlines the history of the theories of continental drift and plate tectonics. This is now familiar ground and my only comment is to regret that Carey here perpetu- ates the notion that Francis Bacon was the first to point out the 'jig-saw' fit of the opposing shores of the Atlantic. Bacon did no such thing. He merely commented that the Old and New Worlds have similar shapes in that they both taper southwards, and in that the outlines of Africa and South America are similar if we compare their equivalent coasts, viz. the 'horn' of East Africa with the 'shoulder' of Brazil and the Gulf of Guinea with the PeruChile bight.

The burden of Carey's thesis is presented in Parts 3, 4 and 5 of the book. There he forcefully presents his case for belief in an expanding Earth, dealing with certain concomitant matters (especially with what he terms "vertical orogenesis") and countering some of the objections which can be raised against his theory. The final part is devoted to cosmological speculations in such areas as Big Bang theory (which Carey rejects), antimatter, black holes and gravity waves. Here, as ever, Carey's writing is both clear and stimulating, although among cosmologists I suspect he will find more opponents than friends.

In publishing this work Carey breaks one of the unwritten rules of the world of science. He claims in his preface that he is addressing "the educated layman" and I am sure that he will be widely read within that sector of society. Here he is making an appeal to the general public over the heads of his scientific peers. But then the same was true of the theory of continental drift in 1915, when Alfred Wegener published his book championing that idea. Today Wegener's Die Entstehung der Kontinente und Ozeane is a revered classic of the Earth sciences. Will Carey's book one day be held in similar esteem?

Gordon L. Herries Davies is a Fellow of Trinity College, Dublin 2, Ireland.

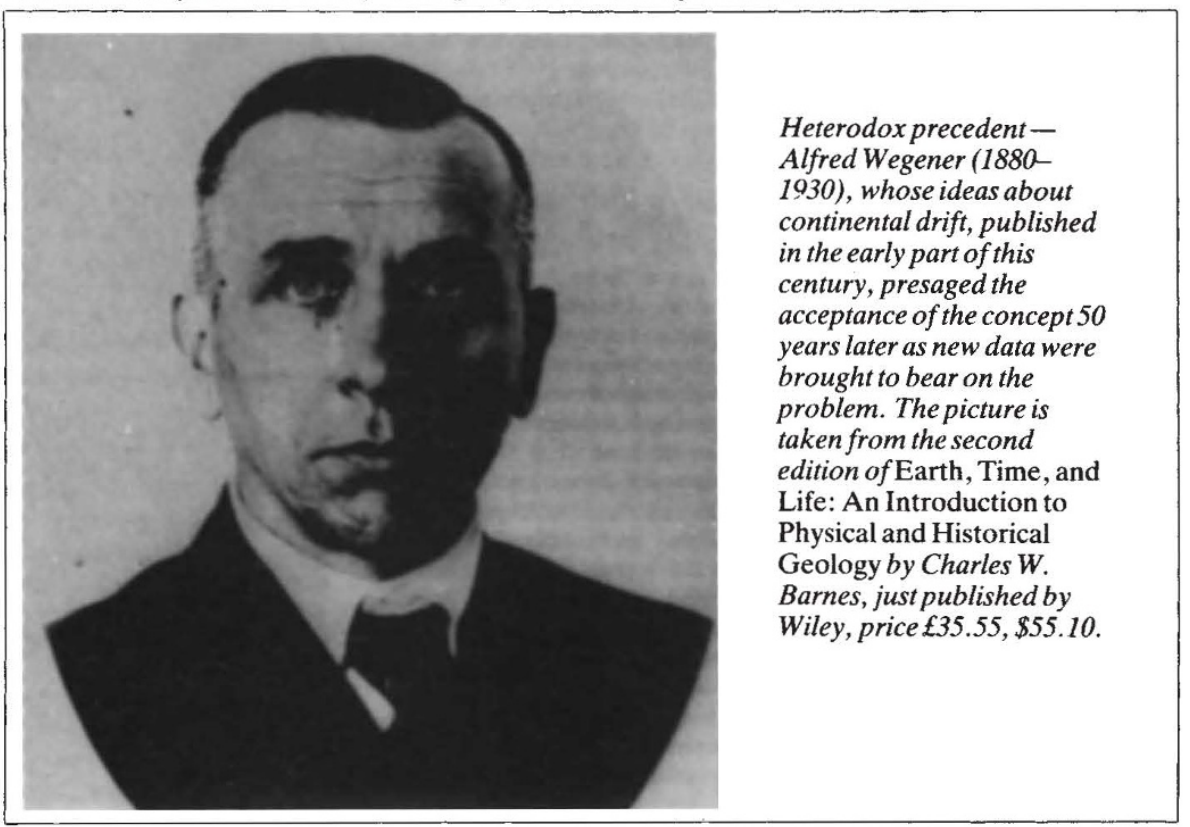

